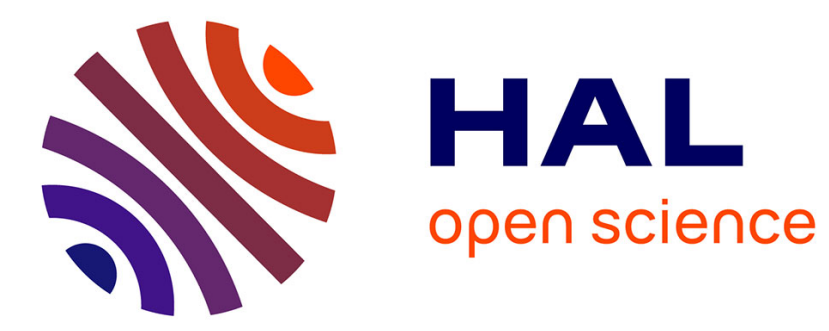

\title{
Ag5U(PS4)3: A Transition-Metal Actinide Phosphochalcogenide
}

Adel Mesbah, Jai Prakash, Sébastien Lebègue, Jessica Beard, Christos. Malliakas, James Ibers

\section{- To cite this version:}

Adel Mesbah, Jai Prakash, Sébastien Lebègue, Jessica Beard, Christos. Malliakas, et al.. Ag5U(PS4)3: A Transition-Metal Actinide Phosphochalcogenide. Inorganic Chemistry, 2019, 58 (1), pp.535-539. 10.1021/acs.inorgchem.8b02739 . hal-02045558

\section{HAL Id: hal-02045558 https://hal.science/hal-02045558}

Submitted on 6 Dec 2020

HAL is a multi-disciplinary open access archive for the deposit and dissemination of scientific research documents, whether they are published or not. The documents may come from teaching and research institutions in France or abroad, or from public or private research centers.
L'archive ouverte pluridisciplinaire HAL, est destinée au dépôt et à la diffusion de documents scientifiques de niveau recherche, publiés ou non, émanant des établissements d'enseignement et de recherche français ou étrangers, des laboratoires publics ou privés. 


\section{$\operatorname{Ag}_{5} \mathrm{U}\left(\mathrm{PS}_{4}\right)_{3}$ : A Transition-Metal Actinide Phosphochalcogenide}

Adel Mesbah,,$+\dagger$ Jai Prakash,,${ }^{\dagger} \S$ Sébiastien Lebègue, ${ }^{\ddagger}$ Jessica C. Beard,${ }^{\dagger}$ Christos. D. Malliakas, ${ }^{\dagger}$ and James A. Ibers ${ }^{\dagger}$

${ }^{\dagger}$ Department of Chemistry, Northwestern University, 2145 Sheridan Road, Evanston, IL 60208-3113, United States.

ICSM, UMR 5257 CEA, CNRS, ENSCM, Univ Montpellier, Site de Marcoule - Bât. 426, BP 17171, 30207 Bagnols-sur-Cèze, France.

${ }^{\S}$ Department of Chemistry, Indian Institute of Technology Hyderabad, Kandi 502 285, Sangareddy, Telangana, India.

${ }^{\ddagger}$ Laboratoire de Physique et Chimie Théoriques (LPCT, UMR CNRS 7019), Institut Jean Barriol, Université de Lorraine, BP 239, Boulevard des Aiguillettes, 54506 Vandoeuvre-lès-Nancy, France.

\footnotetext{
ABSTRACT: The structure of $\mathrm{Ag}_{5} \mathrm{U}\left(\mathrm{PS}_{4}\right)_{3}$ is unique as in the literature there are no other structures of the type MAnPQ $(\mathrm{M}=$ transition metal, $\mathrm{An}=$ actinide, $\mathrm{Q}=\mathrm{S}$, Se, or Te). The compound has been synthesized at $1123 \mathrm{~K}$ by standard solid-state methods and its single-crystal X-ray structure has been determined at $100(2) \mathrm{K} . \mathrm{Ag}_{5} \mathrm{U}\left(\mathrm{PS}_{4}\right)_{3}$ crystallizes in a remarkable new structure type in space group $P 3_{2} 21$ of the trigonal system with three formula units in a hexagonal cell of dimensions $a=b=9.6635(2) \AA, c=17.1834(4) \AA$, and $\gamma=120^{\circ}$. In the structure each $\mathrm{U}$ atom is coordinated to eight $\mathrm{S}$ atoms in a bicapped trigonal prismatic manner. Each $\mathrm{P}$ atom is tetrahedrally coordinated to four $\mathrm{S}$ atoms. Two of the three unique $\mathrm{Ag}$ atoms are connected to four $\mathrm{S}$ atoms in a distorted tetrahedral manner whereas the third unique $\mathrm{Ag}$ atom forms a $\mathrm{Ag}_{2} \mathrm{~S}_{6}$ species. The overall structure consists of $\mathrm{U}$ polyhedra connected to each other via $\mathrm{PS}_{4}$ tetrahedra through edge-sharing in a zig-zag fashion along the $c$ axis to form infinite layers. $\mathrm{PS}_{4}$ groups and the $\mathrm{Ag}$ atoms pack these layers.

From DFT calculations $\mathrm{Ag}_{5} \mathrm{U}\left(\mathrm{PS}_{4}\right)_{3}$ is found to have finite spin polarization in the crystal cell: the magnetic moments of two of the $U$ atoms are parallel, whereas the magnetic moment of the third $U$ atom is antiparallel.
} 


\section{INTRODUCTION}

The search for new actinide chalcogenides $(\mathrm{An}=\mathrm{Th}, \mathrm{U}, \mathrm{Np} ; \mathrm{Q}=\mathrm{S}, \mathrm{Se}, \mathrm{Te})$ has been widely conducted through the use of solid-state methods involving a flux method or direct combination of elements. ${ }^{1-5}$ The phosphochalcogens offer structural flexibility that often leads to a variety of exciting new structures. The greater diversity of stoichiometries among the phosphochalcogens arises from their ability to form $\mathrm{Q}^{-} \mathrm{Q}$ bonds that leads to polymeric substructures such as $\mathrm{PQ}_{3}$, $\mathrm{P}_{2} \mathrm{Q}_{6}, \mathrm{P}_{2} \mathrm{Q}_{10}, \mathrm{P}_{4} \mathrm{Q}_{13}, \mathrm{P}_{6} \mathrm{Q}_{12}$, and $\mathrm{PQ}_{6}{ }^{6-10}$ Known phosphosulfides include ternaries such as $\mathrm{UP}_{1-}$ ${ }_{\mathrm{x}} \mathrm{S}_{\mathrm{x}},{ }^{11} \mathrm{UPS},{ }^{12} \mathrm{ThP}_{2} \mathrm{~S}_{6},{ }^{13} \mathrm{UP}_{2} \mathrm{~S}_{6},{ }^{14} \mathrm{U}_{\left(\mathrm{P}_{2} \mathrm{~S}_{6}\right) 2},{ }^{14} \mathrm{UP}_{2} \mathrm{~S}_{7},{ }^{14,}{ }^{15} \mathrm{UP}_{2} \mathrm{~S}_{9},{ }^{15}$ and $\mathrm{U}_{3}\left(\mathrm{PS}_{4}\right)_{4} ;{ }^{14}$ quaternaries such as $\mathrm{A}_{11} \mathrm{U}_{7}\left(\mathrm{PS}_{4}\right)_{13}(\mathrm{~A}=\mathrm{K}, \mathrm{Rb}),{ }^{16} \mathrm{CsLiU}\left(\mathrm{PS}_{4}\right)_{2}{ }^{17} \mathrm{Cs}_{8} \mathrm{U}_{5}\left(\mathrm{P}_{3} \mathrm{~S}_{10}\right)_{2}\left(\mathrm{PS}_{4}\right)_{6},{ }^{8} \mathrm{~A}_{5} \mathrm{An}\left(\mathrm{PS}_{4}\right)_{3}(\mathrm{~A}=\mathrm{K}$, $\mathrm{Rb}, \mathrm{Cs} ; \mathrm{An}=\mathrm{U}, \mathrm{Th}),{ }^{8} \operatorname{AkAn}\left(\mathrm{PS}_{4}\right)_{2}(\mathrm{Ak}=\mathrm{Sr}, \mathrm{Ba} ; \mathrm{An}=\mathrm{Th}, \mathrm{U}),{ }^{18}$ and $\mathrm{Cs}_{4} \mathrm{Th}_{2} \mathrm{P}_{6} \mathrm{~S}_{18} ;{ }^{19}$ and the quintaries or greater such as $\mathrm{A}_{6} \mathrm{U}_{3} \mathrm{Sb}_{2} \mathrm{P}_{8} \mathrm{~S}_{32},{ }^{20} \mathrm{Cs}_{5} \mathrm{Na}_{6}\left[\mathrm{U}\left(\mathrm{PS}_{4}\right)_{4}\right]\left(\mathrm{PS}_{4}\right),{ }^{21} \mathrm{Rb}_{5} \mathrm{Na}_{3}\left[\mathrm{U}\left(\mathrm{PS}_{4}\right)_{4}\right],{ }^{21}$ $\mathrm{CsNa}\left[\mathrm{U}\left(\mathrm{PS}_{4}\right)_{2}\right],{ }^{21} \quad \mathrm{Cs}_{1.67} \mathrm{Na}_{0.52} \mathrm{I}_{0.19}\left[\mathrm{U}\left(\mathrm{PS}_{4}\right)_{2}\right],{ }^{21} \quad \mathrm{Cs}_{1.033} \mathrm{Na}_{1.343} \mathrm{I}_{0.376}\left[\mathrm{U}\left(\mathrm{PS}_{4}\right)_{2}\right],{ }^{21} \quad$ and $\mathrm{Rb}_{1.35} \mathrm{Na} \mathrm{Na}_{0.93} \mathrm{I}_{0.28}\left[\mathrm{U}\left(\mathrm{PS}_{4}\right)_{2}\right] .{ }^{21}$ But there are also examples of phosphoselenides and less so of phosphotellurides. These include AnPSe $(\mathrm{An}=\mathrm{U}, \quad \mathrm{Th}),{ }^{22,}{ }^{23} \mathrm{~K}_{2} \mathrm{U}\left(\mathrm{P}_{3} \mathrm{Se}_{9}\right),{ }^{24}$ $\mathrm{Rb}_{4} \mathrm{U}_{2}\left(\mathrm{P}_{2} \mathrm{Se}_{6}\right)_{2.5}\left(\mathrm{Se}_{2}\right),{ }^{25} \mathrm{Cs}_{2} \mathrm{An}_{2}\left(\mathrm{P}_{2} \mathrm{Se}_{9}\right)\left(\mathrm{Se}_{2}\right)_{2} \quad(\mathrm{An}=\mathrm{U}, \mathrm{Th}),{ }^{26,}{ }^{27} \mathrm{Rb}_{7} \mathrm{Th}_{2}\left(\mathrm{PSe}_{4}\right)_{3}\left(\mathrm{P}_{2} \mathrm{Se}_{6}\right)_{1.5},{ }^{19}$ $\mathrm{A}_{2} \mathrm{Th}\left(\mathrm{P}_{3} \mathrm{Se}_{9}\right)(\mathrm{A}=\mathrm{K}, \mathrm{Rb}){ }^{28} \mathrm{Cs}_{4} \mathrm{Th}_{2} \mathrm{P}_{5} \mathrm{Se}_{17}{ }^{28}$ for the selenides and only AnPTe $(\mathrm{An}=\mathrm{U}$, Th) for tellurides. ${ }^{29}$

In the present paper, we report the synthesis, crystal structure, and electronic structure of the compound $\mathrm{Ag}_{5} \mathrm{U}\left(\mathrm{PS}_{4}\right)_{3}$. Its structure is the first example of an actinide transition-metal phosphochalcogenide.

\section{EXPERIMENTAL METHODS}

Synthesis and Analyses. Caution! Depleted $U$ is an $\alpha$-emitting radioisotope and as such is considered a health risk. Experiments using radioisotopes require appropriate infrastructure and personnel trained in the handling of radioactive materials.

The following reactants were used as supplied: Ba (Johnson Matthey, 99.5\%), $\mathrm{P}_{2} \mathrm{~S}_{5}$ (Aldrich, 99\%), S (Mallinckrodt 99.6\%), and Ag (Aldrich, 99.99\%). Depleted U powder was 
obtained after hydridization of $\mathrm{U}$ chips (IBI Laboratories) in a modification ${ }^{30}$ of previous procedure. $^{31}$

Synthesis of $\mathbf{A g}_{5} \mathbf{U}\left(\mathbf{P S}_{4}\right)_{3}$. In attempts to prepare a possible quintary compound containing $\mathrm{Ba}, \mathrm{Ag}, \mathrm{U}, \mathrm{P}$, and $\mathrm{S}$ black blocks what turned out to be $\mathrm{Ag}_{5} \mathrm{U}\left(\mathrm{PS}_{4}\right)_{3}$ were obtained in a reaction of $\mathrm{U}(20.23 \mathrm{mg}, 0.085 \mathrm{mmol}), \mathrm{Ag}(18.32 \mathrm{mg}, 0.17 \mathrm{mmol}), \mathrm{Ba}(35.01 \mathrm{mg}, 0.255$ $\mathrm{mmol}), \mathrm{P}_{2} \mathrm{~S}_{5}(56.61 \mathrm{mg}, 0.255 \mathrm{mmol})$, and $\mathrm{S}(16.35 \mathrm{mg}, 0.510 \mathrm{mmol})$. The reactants were weighed and transferred into a $6 \mathrm{~mm}$ carbon-coated fused-silica tube inside an Ar-filled dry box. The silica tube containing the mixture was then evacuated to $10^{-4}$ Torr, flame sealed, and heated to $1123 \mathrm{~K}$ in a computer-controlled furnace, held at that temperature for $96 \mathrm{~h}$, and then cooled at a rate of $2.5 \mathrm{Kh}^{-1}$ to $673 \mathrm{~K}$, and finally the furnace was turned off. The reaction produced single-crystal black blocks of different sizes. Semi-quantitative analyses of these were obtained via EDX with the use of a Hitachi S-3400 SEM. Small blocks of a size suitable for single-crystal structure determination showed a composition $\mathrm{Ag}: \mathrm{U}: \mathrm{P}: \mathrm{S} \approx 5: 1: 3: 12$. Some of the larger crystals analyzed consistent with $\mathrm{UP}_{2} \mathrm{~S}_{6} .{ }^{14}$

Structure Determination. Single-crystal X-Ray diffraction data for $\mathrm{Ag}_{5} \mathrm{U}\left(\mathrm{PS}_{4}\right)_{3}$ were collected at 100(2) K using a Bruker APEX2 Kappa diffractometer equipped with the $\mathrm{CuK \alpha}(\lambda$ $=1.54178 \AA$ ) radiation. By the use of the algorithm COSMO in APEX $2^{32}$ the data collection comprised a combination of $\omega$ and $\varphi$ scans with steps of $0.3^{\circ}$ and counting time of $10 \mathrm{~s} /$ frame. Recorded data were indexed, refined, and integrated by SAINT in the APEX2 package. ${ }^{32}$ The crystal-to-detector-distance was $40 \mathrm{~mm}$. Face-indexed absorption, incident beam, and decay corrections were performed with the use of the program SADABS. ${ }^{33}$ Precession images constructed from the data set showed no indication of super cells or modulation. The structure was difficult to solve. Ultimately, the program $\mathrm{XT}^{34}$ provided a solution that could be refined with the use of programs in the SHELXTL 2014 package. ${ }^{33,} 35$ The asymmetric unit contains one $\mathrm{U}$, three $\mathrm{Ag}$, two $\mathrm{P}$, and $6 \mathrm{~S}$ atoms, with atoms $\mathrm{U} 1$ and $\mathrm{P} 2$ having .2. symmetry. The anisotropic refinement of the atoms suggests some disorder in the Ag2 atoms. The occupancy of the Ag1 site was not constrained by symmetry and ultimately refined to 0.503(3). Consequently, this occupancy was set to 0.5 to give the formula $\mathrm{Ag}_{5} \mathrm{UP}_{3} \mathrm{~S}_{12}$, which is consistent with the EDX results. Further details are provided in Table 1and in Supporting Information. 
Theoretical Calculations. These have been conducted with density functional theory ${ }^{36,}$

${ }^{37}$ using the projector augmented wave method ${ }^{38}$ as implemented in the VASP (Vienna ab Initio Simulation Package $)^{39,40}$ code. The generalized gradient approximation of Perdew, Burke and Ernzerhof ${ }^{41}$ in its spin polarized version was used as the exchange and correlation potential. The parameters of the cell and the positions of the atoms were taken from the experiment, but because the experimental structure contains one $\mathrm{Ag}$ site that is half occupied we have created several models consistent with the chemical formula $\mathrm{Ag}_{15} \mathrm{U}_{3} \mathrm{P}_{9} \mathrm{~S}_{36}$ in the following way: all the equivalent positions of this site were generated and then models were produced after populating half the Ag1 atoms while keeping the remaining unoccupied. This can be done in different ways, and we have retained the one with the lowest total energy for our analysis. The criterion for the convergence of the total energy was set to $10^{-6} \mathrm{eV}$ To obtain a sufficient convergence, a $2 \times 2 \times 1$ mesh was used for the Brillouin zone. The default value was used for the cut-off of the plane wave part of the wave function.

\section{RESULTS}

Synthesis. The reaction of $\mathrm{Ba}, \mathrm{Ag}, \mathrm{U}, \mathrm{P}_{2} \mathrm{~S}_{5}$, and $\mathrm{S}$ at $1123 \mathrm{~K}$ resulted in the formation of black blocks of $\mathrm{Ag}_{5} \mathrm{U}\left(\mathrm{PS}_{4}\right)_{3}$ in a yield of about $50 \mathrm{wt} \%$ yield based on the $\mathrm{U}$ content. Side products included $\mathrm{UP}_{2} \mathrm{~S}_{6}$ and $\mathrm{BaS}$. The isolated crystals of $\mathrm{Ag}_{5} \mathrm{U}\left(\mathrm{PS}_{4}\right)_{3}$ were stable in oil for a few weeks. Unfortunately, by the time we knew the composition and the nature of the structure, the isolated crystals had decomposed.

Structure. A search of the ICSD data base failed to reveal any structures of the type MAnPQ $(\mathrm{M}=$ transition metal, $\mathrm{An}=$ actinide, $\mathrm{Q}=\mathrm{S}$, Se, or Te $)$; however, it did display the isostructural compounds $\mathrm{AgLn}\left(\mathrm{P}_{2} \mathrm{Se}_{6}\right)(\mathrm{Ln}=$ rare earth $=\mathrm{Sc}, \mathrm{Er}, \mathrm{Tm}) .{ }^{42}$ The structure of these isostructural compounds is layered and very different from that of $\mathrm{Ag}_{5} \mathrm{U}\left(\mathrm{PS}_{4}\right)_{3}$. $\mathrm{Ag}_{5} \mathrm{U}\left(\mathrm{PS}_{4}\right)_{3}$ crystallizes in a remarkable new structure type in space group $P 3_{2} 21$ of the trigonal system with three formula units in a hexagonal cell of dimensions $a=b=9.6635$ (2) $\AA, c=17.1834$ (4) $\AA$, and $\gamma=120^{\circ}$. The asymmetric unit contains one $\mathrm{U}$, three $\mathrm{Ag}$, two $\mathrm{P}$, and six $\mathrm{S}$ atoms. All are in general positions except atoms $\mathrm{U} 1$ and $\mathrm{P} 2$, which have .2. site symmetry.

A projection down the [110] direction of the $\mathrm{Ag}_{5} \mathrm{U}\left(\mathrm{PS}_{4}\right)_{3}$ crystal structure is shown in Figure 1. Each $\mathrm{U} 1$ atom is coordinated to eight $\mathrm{S}$ atoms in a bicapped trigonal prismatic manner. 
Each $\mathrm{P}$ atom is tetrahedrally coordinated to four $\mathrm{S}$ atoms. Each of the Ag1 and Ag3 atoms is connected to four $\mathrm{S}$ atoms in a distorted tetrahedral manner. In contrast, the Ag2 atoms exhibit a $\mathrm{Ag} 2-\mathrm{Ag} 2$ short distance of 2.774(5) $\AA$ and form a $\mathrm{Ag}_{2} \mathrm{~S}_{6}$ species. The $\mathrm{Ag}-\mathrm{S}$ network is presented in Figure 2. The overall structure consists of $U$ polyhedra connected to each other via $\mathrm{P}_{2} \mathrm{~S}_{4}$ tetrahedra through edge-sharing in a zig-zag fashion along the $c$ axis to form infinite layers. The $\mathrm{P}_{1 \mathrm{~S}}$ and the $\mathrm{Ag}$ atoms pack these layers.

The U1-S distances in the structure of $\mathrm{Ag}_{5} \mathrm{U}\left(\mathrm{PS}_{4}\right)_{3}$ range from 2.784(5) to 2.851(5) $\AA$,

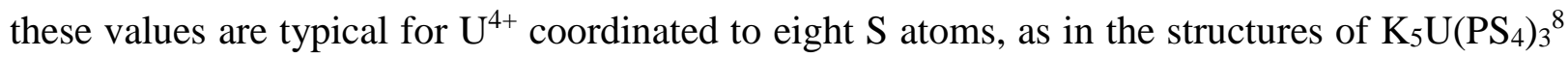
(2.802(2) to $3.021(2) \AA)$; $\mathrm{CsLiU}\left(\mathrm{PS}_{4}\right)_{2}{ }^{17}$ (2.768(1) to $\left.2.884(1) \AA\right) ; \mathrm{K}_{11} \mathrm{U}_{7}\left(\mathrm{PS}_{4}\right)_{13}{ }^{16}$ (2.772(4) to

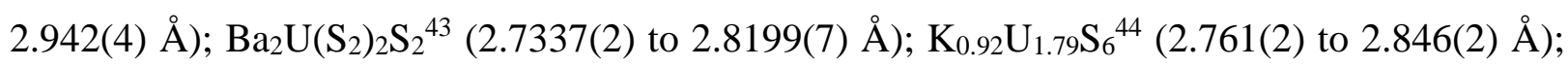
$\mathrm{Rb}_{0.85} \mathrm{U}_{1.74} \mathrm{~S}_{6}{ }^{45}$ (2.775(3) to 2.847(2) $\AA$ ); and $\mathrm{RbSbU}_{2} \mathrm{SS}_{8}{ }^{46}$ (2.752(3) to 2.854(1) $\AA$ ). The $\mathrm{Ag}-\mathrm{S}$ distances in the structure of $\mathrm{Ag}_{5} \mathrm{U}\left(\mathrm{PS}_{4}\right)_{3}$ range from 2.429(6) to 2.917(6) $\AA$. These distances may be compared with those in structures having $\mathrm{Ag}^{+}$in similar coordination as in $\mathrm{Ba}_{9} \mathrm{Ag}_{10} \mathrm{U}_{4} \mathrm{~S}_{24}{ }^{47}$ (2.526(2) to 2.852(4) $\AA$ ); $\mathrm{Ag}_{2} \mathrm{CdGeS}_{4}{ }^{48}$ (2.522(1) to 2.570(1) $\AA$ ); $\mathrm{CsAgSb}_{4} \mathrm{~S}_{7}{ }^{49}$ (2.502(1) to 2.864(1) $\AA$ ); $\mathrm{KAg}(\mathrm{SCN})_{2}{ }^{50}$ (2.577(6) to2.7262(5) $\AA$ ); and $\mathrm{La}_{4} \mathrm{Ag}_{2} \mathrm{In}_{4} \mathrm{~S}_{13}{ }^{51}$ (2.659(1) to $2.933(1) \AA$ ). The $\mathrm{P}-\mathrm{S}$ distances in the structure of $\mathrm{Ag}_{5} \mathrm{U}\left(\mathrm{PS}_{4}\right)_{3}$ range from 2.008(7) to 2.064(7) $\AA$. These are typical for $\mathrm{P}^{5+}$ in tetrahedral coordination as in the structures of $\left.\mathrm{K}_{5} \mathrm{U}\left(\mathrm{PS}_{4}\right)_{3}\right)^{8}$ (2.005(2) to 2.083(2) $\AA$ ); $\mathrm{CsLiU}\left(\mathrm{PS}_{4}\right)_{2}{ }^{17}$ (2.024(2) to 2.047(2) $\AA$ ); and $\mathrm{SrU}\left(\mathrm{PS}_{4}\right)_{2}$ and $\mathrm{BaU}\left(\mathrm{PS}_{4}\right)_{2}$ with the values of $2.000(1)$ to $2.063(1) \AA$ and $1.996(2)$ to $2.059(2) \AA$, respectively. ${ }^{18}$

The Ag2-Ag2 short distance of 2.774(5) $\AA$ is not atypical, as there are many examples in the CCDC database. Two examples are $2.772 \AA$ in $\left[\mathrm{Ag}_{2}(\mathrm{obpy})_{2}\right]_{2} \cdot 14.5 \mathrm{H}_{2} \mathrm{O}^{52}$, where obpy =2,2'bipyridinyl-6-one and $2.773 \AA$ in $\mathrm{Ag}_{2} \mathrm{C}_{2} \cdot 2 \mathrm{AgCF}_{3} \mathrm{CO}_{2} \cdot 2 \mathrm{Ag}_{2} \mathrm{PhPO}_{3} \cdot \mathrm{Ag}_{3}\left[\left(\mathrm{PhPO}_{3}\right)_{2} \mathrm{H}\right]^{53}$.

The crystal structure of the $\mathrm{Ag}_{5} \mathrm{U}\left(\mathrm{PS}_{4}\right)_{3}$ has no $\mathrm{S}-\mathrm{S}$ short distances and thus the assignment of formal oxidation states is straightforward: $5 \times \mathrm{Ag}^{+}, 1 \times \mathrm{U}^{4+}, 3 \times \mathrm{P}^{5+}, 12 \times \mathrm{S}^{2-}$.

DFT Calculations. $\mathrm{Ag}_{5} \mathrm{U}\left(\mathrm{PS}_{4}\right)_{3}$ is found to have finite spin polarization in the crystal cell: the magnetic moments of two of the $U$ atoms are parallel, whereas the magnetic moment of the third $U$ atom is antiparallel. This is seen in Figure 3 where the total density of states (top plot) is asymmetric with respect to spin. The partial density of states for each inequivalent atom in the cell is also presented in Figure 3. Most of the magnetic moment is carried by the $\mathrm{U}$ atoms 
which induces a small magnetization on the neighboring atoms. Also, the states at the Fermi level mostly arise from the $\mathrm{U}$.

\section{CONCLUSIONS}

$\mathrm{Ag}_{5} \mathrm{U}\left(\mathrm{PS}_{4}\right)_{3}$ has a unique structure as there appear to be no other known structures of the type MAnPQ $(\mathrm{M}=$ transition metal, $\mathrm{An}=$ actinide, $\mathrm{Q}=\mathrm{S}$, Se, or $\mathrm{Te}) . \mathrm{Ag}_{5} \mathrm{U}\left(\mathrm{PS}_{4}\right)_{3}$ crystallizes in a remarkable new structure type in space group $P 3_{2} 21$ of the trigonal system with three formula units in a hexagonal cell of dimensions $a=b=9.6635(2) \AA, c=17.1834(4) \AA$, and $\gamma=120^{\circ}$. The asymmetric unit contains one $\mathrm{U}$, three $\mathrm{Ag}$, two $\mathrm{P}$, and six $\mathrm{S}$ atoms. All are in general positions except atoms $\mathrm{U} 1$ and $\mathrm{P} 2$, which have .2. site symmetry. In the structure each $\mathrm{U}$ atom is coordinated to eight $\mathrm{S}$ atoms in a bicapped trigonal prismatic manner. Each $\mathrm{P}$ atom is tetrahedrally coordinated to four S atoms. Two of the three unique Ag atoms are connected to four $\mathrm{S}$ atoms in a distorted tetrahedral manner whereas the third $\mathrm{Ag}$ atom forms a $\mathrm{Ag}_{2} \mathrm{~S}_{6} \mathrm{species}_{\text {. }}$ The overall structure consists of U polyhedra connected to each other via $\mathrm{PS}_{4}$ tetrahedra through edge-sharing in a zig-zag fashion along the $c$ axis to form infinite layers. $\mathrm{PS}_{4}$ groups and the $\mathrm{Ag}$ atoms pack these layers. The crystal structure of the $\mathrm{Ag}_{5} \mathrm{U}\left(\mathrm{PS}_{4}\right)_{3}$ has no S-S short distances and thus the assignment of formal oxidation states is straightforward: $5 \times \mathrm{Ag}^{+}, 1 \times \mathrm{U}^{4+}, 3 \times \mathrm{P}^{5+}, 12 \times$ $\mathrm{S}^{2-}$.

From DFT calculations $\mathrm{Ag}_{5} \mathrm{U}\left(\mathrm{PS}_{4}\right)_{3}$ is found to have finite spin polarization in the crystal cell: the magnetic moments of two of the $U$ atoms are parallel, whereas the magnetic moment of the third $\mathrm{U}$ atom is antiparallel.

\section{ASSOCIATED CONTENT}

\section{Supporting Information}

The crystallographic CIF file for $\mathrm{Ag}_{5} \mathrm{U}\left(\mathrm{PS}_{4}\right)_{3}$ has been deposited with $\mathrm{CCDC}$ (https://www.ccdc.cam.ac.uk) as entry CCDC1866631. 


\section{AUTHOR INFORMATION}

*E-mail: ibers@chem.northwestern.edu

Notes

The authors declare no competing financial interest.

\section{ACKNOWLEDGMENTS}

Use was made of the IMSERC X-ray Facility at Northwestern University, which has received support from the Soft and Hybrid Nanotechnology Experimental (SHyNE) Resource (NSF ECCS-1542205); the State of Illinois, and International Institute for Nanotechnology (IIN). We have benefited from discussions with Prof. George Sheldrick concerning the crystal structure. 


\section{REFERENCES}

(1) Mesbah, A.; Prakash, J.; Ibers, J. A. Overview of the crystal chemistry of the actinide chalcogenides: incorporation of the alkaline-earth elements. Dalton Trans. 2016, 45, 16067-16080.

(2) Manos, E.; Kanatzidis, M. G.; Ibers, J. A. In The Chemistry of the Actinide and Transactinide Elements, 4th ed.; Morss, L. R.; Edelstein, N. M.; Fuger, J., Eds.; Springer: Dordrecht, The Netherlands, 2010; Vol. 6, pp. 4005-4078.

(3) Bugaris, D. E.; Ibers, J. A. Syntheses and characterization of some solid-state actinide (Th,U,Np) compounds. Dalton Trans. 2010, 39, 5949-5964.

(4) Narducci, A. A.; Ibers, J. A. Ternary and Quaternary Uranium and Thorium Chalcogenides. Chem. Mater. 1998, 10, 2811-2823.

(5) Koscielski, L. A.; Ibers, J. A. The Structural Chemistry of Quaternary Chalcogenides of the Type AMM'Q3. Z. Anorg. Allg. Chem. 2012, 638, 2585-2593.

(6) Chondroudis, K.; Kanatzidis, M. G. $\mathrm{Rb}_{4} \mathrm{Sn}_{2} \mathrm{Ag}_{4}\left(\mathrm{P}_{2} \mathrm{Se}_{6}\right)_{3}$ : First Example of a Quinary Selenophosphate and an Unusual Sn-Ag s${ }^{2}-\mathrm{d}^{10}$ Interaction. Inorg. Chem. 1998, 37, 28482849.

(7) Gieck, C.; Rocker, F.; Ksenofontov, V.; Gütlich, P.; Tremel, W. "Supramolecular" Solid-State Chemistry: Interpenetrating Diamond-Type Frameworks of $\mathrm{U}^{4+}$ Ions Linked by $\mathrm{S}, \mathrm{S}^{\prime}-$ Bidentate $\mathrm{P}_{2} \mathrm{~S}_{6}{ }^{2-}$ Molecular Rods in $\mathrm{UP}_{4} \mathrm{~S}_{12}$. Angew. Chem., Int. Ed. Engl. 2001, 40, 908-911.

(8) Hess, R. F.; Abney, K. D.; Burris, J. L.; Hochheimer, H. D.; Dorhout, P. K. Synthesis and Characterization of Six New Quaternary Actinide Thiophosphate Compounds: 
$\mathrm{Cs}_{8} \mathrm{U}_{5}\left(\mathrm{P}_{3} \mathrm{~S}_{10}\right)_{2}\left(\mathrm{PS}_{4}\right)_{6}, \mathrm{~K}_{10} \mathrm{Th}_{3}\left(\mathrm{P}_{2} \mathrm{~S}_{7}\right)_{4}\left(\mathrm{PS}_{4}\right)_{2}$, and $\mathrm{A}_{5} \mathrm{An}\left(\mathrm{PS}_{4}\right)_{3},(\mathrm{~A}=\mathrm{K}, \mathrm{Rb}, \mathrm{Cs} ; \mathrm{An}=\mathrm{U}$, Th). Inorg. Chem. 2001, 40, 2851-2859.

(9) Wu, Y.; Bensch, W. $\mathrm{Rb}_{3} \mathrm{Ti}_{3}\left(\mathrm{P}_{3} \mathrm{~S}_{13}\right)\left(\mathrm{PS}_{4}\right)_{3}$ and $\mathrm{Cs}_{2} \mathrm{Ti}_{2}\left(\mathrm{P}_{2} \mathrm{~S}_{8}\right)\left(\mathrm{PS}_{4}\right)$ : Two Polar Titanium Thiophosphates with Complex One-Dimensional Tunnels. Inorg. Chem. 2007, 46, 61706177.

(10) Cody, J. A.; Finch, K. B.; Reynders, G. J.; Alexander, G. C. B.; Lim, H. G.; Nather, C.; Bensch, W. Ionothermal Synthesis of Four New Nickel Thiophosphate Anions: $\left[\mathrm{Ni}\left(\mathrm{P}_{2} \mathrm{~S}_{8}\right)_{2}\right]^{2-},\left[\mathrm{Ni}\left(\mathrm{P}_{3} \mathrm{~S}_{9}\left(\mathrm{P}_{2} \mathrm{~S}_{8}\right)\right]^{3-},\left[\mathrm{Ni}_{(}\left(\mathrm{P}_{3} \mathrm{~S}_{9}\right)_{2}\right]^{4-}\right.$, and $\left[\left(\mathrm{NiP}_{3} \mathrm{~S}_{8}\right)_{4}\left(\mathrm{PS}_{4}\right)\right]^{7-}$. Inorg. Chem. 2012, $51,13357-13362$.

(11) Baskin, Y.; Shalek, P. D. Melting Point Studies of the System UP-US. J. Am. Ceram. Soc. 1969, 52, 341-342.

(12) Kaczorowski, D.; Noël, H.; Potel, M.; Zygmunt, A. Crystal Structure, Magnetic and Electrical Transport Properties of UPS Single Crystals. J. Phys. Chem. Solids 1994, 55, 1363-1367.

(13) Simon, A.; Peters, K.; Peters, E.-M. Darstellung und Kristallstruktur von $\mathrm{ZrP}_{2} \mathrm{~S}_{6}$ und $\mathrm{ThP}_{2} \mathrm{~S}_{6}$. Z. Anorg. Allg. Chem. 1982, 491, 295-300.

(14) Neuhausen, C.; Hatscher, S. T.; Panthofer, M.; Urland, W.; Tremel, W. Comprehensive Uranium Thiophosphate Chemnistry: Framework Compounds Based on Pseudotetrahedrally Coordinated Central Metal Atoms. Z. Anorg. Allg. Chem. 2013, $639,2836-2845$.

(15) Babo, J.-M.; Jouffret, L.; Lin, J.; Villa, E. M.; Albrecht-Schmitt, T. E. Synthesis, Structure, and Spectroscopy of Two Ternary Uranium(IV) Thiphosphates: $\mathrm{UP}_{2} \mathrm{~S}_{9}$ and $\mathrm{UP}_{2} \mathrm{~S}_{7}$ Containing $\mathrm{P}_{2} \mathrm{~S}_{9}{ }^{2-}$ and $\mathrm{P}_{2} \mathrm{~S}_{7}{ }^{2-}$ Ligands. Inorg. Chem. 2013, 52, 7747-7751. 
(16) Gieck, C.; Tremel, W. Interlocking Inorganic Screw Helices: Synthesis, Structure, and Magnetism of the Novel Framework Uranium Orthothiophosphates $\mathrm{A}_{11} \mathrm{U}_{7}\left(\mathrm{PS}_{4}\right)_{13}(\mathrm{~A}=$ K,Rb). Chem. Eur. J. 2002, 8, 2980-2987.

(17) Neuhausen, C.; Rocker, F.; Tremel, W. Modular Metal Chalcogenide Chemistry: Secondary Building Blocks as a Basis of the Silicate-Type Framework Structure of CsLiU(PS 4$)_{2}$. Z. Anorg. Allg. Chem. 2012, 638, 405-410.

(18) Mesbah, A.; Prakash, J.; Beard, J. C.; Lebègue, S.; Malliakas, C. D.; Ibers, J. A. Syntheses, Crystal Structures, Optical and Theoretical Studies of the Actinide Thiophosphates $\mathrm{SrU}\left(\mathrm{PS}_{4}\right)_{2}, \mathrm{BaU}\left(\mathrm{PS}_{4}\right)_{2}$, and $\mathrm{SrTh}\left(\mathrm{PS}_{4}\right)_{2}$. Inorg. Chem. 2015, 54, 29702975.

(19) Chan, B. C.; Hess, R. F.; Feng, P. L.; Abney, K. D.; Dorhout, P. K. Synthesis and Characterization of Two Quaternary Thorium Chalcophosphates: $\mathrm{Cs}_{4} \mathrm{Th}_{2} \mathrm{P}_{6} \mathrm{~S}_{18}$ and $\mathrm{Rb}_{7} \mathrm{Th}_{2} \mathrm{P}_{6} \mathrm{Se}_{21}$. Inorg. Chem. 2005, 44, 2106-2113.

(20) Babo, J.-M.; Diefenbach, K.; Albrecht-Schmitt, T. $\mathrm{A}_{6} \mathrm{U}_{3} \mathrm{Sb}_{2} \mathrm{P}_{8} \mathrm{~S}_{32}(\mathrm{~A}=\mathrm{Rb}, \mathrm{Cs})$ : Quinary Uranium (IV)Thiophosphates Containing the $\left[\mathrm{Sb}\left(\mathrm{PS}_{4}\right)_{3}\right]^{6-}$ Anion. Inorg. Chem. 2014, 53, 3540-3545.

...(21) Klepov, V. V.; zur Loye, H. -C. Complex Topologies from Simple Building Blocks: Uranium(IV) Thiophosphates. Inorg. Chem. 2018, 57, 11175-11183.

(22) Oh, G. N.; Ibers, J. A. The beta-polymorph of uranium phosphide selenide. Acta Cryst. Sect. E: Struct. Rep. Online 2011, 67, i75.

(23) Hulliger, F. New Ternary Thorium and Uranium Compounds MYX. J. Less-Common Met. 1968, 16, 113-117. 
(24) Chondroudis, K.; Kanatzidis, M. G. Synthesis and Characterization of $\mathrm{K}_{2} \mathrm{UP}_{3} \mathrm{Se}_{9}$. The First Actinide Selenophosphate. C. R. Acad. Sci. Paris 1996, 322, 887-894.

(25) Bellott, B. J.; Ibers, J. A. Synthesis and Structure of the Rubidium Uranium Selenophosphate $\mathrm{Rb}_{4} \mathrm{U}_{2} \mathrm{P}_{5} \mathrm{Se}_{17}$. Z. Anorg. Allg. Chem. 2012, 638, 2473-2476.

(26) Briggs Piccoli, P. M.; Abney, K. D.; Schoonover, J. D.; Dorhout, P. K. Synthesis, Structure, and Properties of $\mathrm{Cs}_{4} \mathrm{Th}_{4} \mathrm{P}_{4} \mathrm{Se}_{26}$ : A Quaternary Thorium Selenophosphate Containing the $\left(\mathrm{P}_{2} \mathrm{Se}_{9}\right)^{6-}$ Anion. Inorg. Chem. 2001, 40, 4871-4875.

(27) Mesbah, A.; Prakash, J.; Beard, J. C.; Lebègue, S.; Ibers, J. A. Synthesis and Crystal Structure of $\mathrm{Cs}_{2} \mathrm{U}_{2}\left(\mathrm{P}_{2} \mathrm{Se}_{9}\right)\left(\mathrm{Se}_{2}\right)_{2}$. Z. Anorg. Allg. Chem. 2018 (in print), DOI:10.1002/zaac.201800263.

(28) Briggs Piccoli, P. M.; Abney, K. D.; Schoonover, J. R.; Dorhout, P. K. Synthesis and Structural Characterization of Quaternary Thorium Selenophosphates: $\mathrm{A}_{2} \operatorname{ThP}_{3} \mathrm{Se}_{9}(\mathrm{~A}=$ $\mathrm{K}, \mathrm{Rb}$ ) and $\mathrm{Cs}_{4} \mathrm{Th}_{2} \mathrm{P}_{5} \mathrm{Se}_{17}$. Inorg. Chem. 2000, 39, 2970-2976.

(29) Stolze, K.; Isaeva, A.; Schwarz, U.; Doert, T. UPTe, ThPTe and $\mathrm{U}_{2} \mathrm{PTe}_{2} \mathrm{O}$ : actinide pnictide chalcogenides with diphosphide anions. Eur. J. Inorg. Chem. 2015, 2015, 778785.

(30) Bugaris, D. E.; Ibers, J. A. Syntheses, structures, and magnetic and optical properties of the compounds $\left[\mathrm{Hg}_{3} \mathrm{Te}_{2}\right]\left[\mathrm{UCl}_{6}\right]$ and $\left[\mathrm{Hg}_{4} \mathrm{As}_{2}\right]\left[\mathrm{UCl}_{6}\right]$. J. Solid State Chem. 2008, 181, 3189-3193.

(31) Haneveld, A. J. K.; Jellinek, F. Some Ternary Uranium Chalcogenides. J. Less-Common Met. 1969, 18, 123-129. 
(32) Bruker APEX2 Version 2009.5-1 Data Collection and Processing Software; Bruker Analytical X-Ray Instruments, Inc.: Madison, WI, USA, 2009.

(33) Sheldrick, G. M. SADABS; Department of Structural Chemistry, University of Göttingen, Göttingen, Germany, 2008.

(34) Sheldrick, G. M. SHELXT-Integrated space-group and crystal-structure determination. Acta Crystallogr. Sect. A: Found. Crystallogr. 2015, 71, 3-8.

(35) Sheldrick, G. M. A short history of SHELX. Acta Crystallogr. Sect. A: Found. Crystallogr. 2008, 64, 112-122.

(36) Kohn, W.; Sham, L. J. Self-Consistent Equations Including Exchange and Correlation Effects. Phys. Rev. 1965, 140, 1133-1138.

(37) Hohenberg, P.; Kohn, W. Inhomogeneous Electron Gas. Phys. Rev. 1964, 136, 864-871.

(38) Blöchl, P. E. Projector augmented-wave method. Phys. Rev. B 1994, 50, 17953-17979.

(39) Kresse, G.; Forthmüller, J. Efficiency of ab-initio total energy calculations for metals and semiconductors using a plane-wave basis set. Comput. Mater. Sci. 1996, 6, 15-50.

(40) Kresse, G.; Joubert, D. From ultrasoft pseudopotentials to the projector augmented-wave method. Phys. Rev. B 1999, 59, 1758-1775.

(41) Perdew, J. P.; Burke, K.; Ernzerhof, M. Generalized Gradient Approximation Made Simple. Phys. Rev. Lett. 1996, 77, 3865-3868.

(42) Pfitzner, A.; Seidlmayer, S. Synthesis and Structure Determination of $\mathrm{AgScP}_{2} \mathrm{Se}_{6}$, $\mathrm{AgErP}_{2} \mathrm{Se}_{6}$ and $\mathrm{AgTmP}_{2} \mathrm{Se}_{6}$. Z. Anorg. Allg. Chem. 2009, 635, 704-707. 
(43) Mesbah, A.; Ringe, E.; Lebègue, S.; Van Duyne, R. P.; Ibers, J. A. Ba $\mathrm{Ban}\left(\mathrm{S}_{2}\right)_{2} \mathrm{~S}_{2}(\mathrm{An}=$ U, Th): Syntheses, Structures, Optical, and Electronic Properties. Inorg. Chem. 2012, 51, 13390-13395.

(44) Mizoguchi, H.; Gray, D.; Huang, F. Q.; Ibers, J. A. Structures and bonding in $\mathrm{K}_{0.91} \mathrm{U}_{1.79} \mathrm{~S}_{6}$ and $\mathrm{KU}_{2} \mathrm{Se}_{6}$. Inorg. Chem. 2006, 45, 3307-3311.

(45) Bugaris, D. E.; Wells, D. M.; Yao, J.; Skanthakumar, S.; Haire, R. G.; Soderholm, L.; Ibers, J. A. Dichalcogenide Bonding in Seven Alkali-Metal Actinide Chalcogenides of the $\mathrm{KTh}_{2} \mathrm{Se}_{6}$ Structure Type. Inorg. Chem. 2010, 49, 8381-8388.

(46) Choi, K.-S.; Kanatzidis, M. G. New Uranium Chalcoantimonates, $\mathrm{RbU}_{2} \mathrm{SbS}_{8}$ and $\mathrm{KU}_{2} \mathrm{SbSe}_{8}$, with a Polar Noncentrosymmetric Structure. Chem. Mater. 1999, 11, 26132618.

(47) Mesbah, A.; Stojko, W.; Lebègue, S.; Malliakas, C. D.; Frazer, L.; Ibers, J. A. The U ${ }^{5+}$ Compound Ba9 $\mathrm{Ag}_{10} \mathrm{U}_{4} \mathrm{~S}_{24}$ : Synthesis, Structure, and Electronic Properties. J. Solid State Chem. 2015, 221, 398-404.

(48) Parasyuk, O. V.; Piskach, L. V.; Olekseyuk, I. D.; Pekhnyo, V. I. The quasi-ternary system $\mathrm{Ag}_{2} \mathrm{~S}-\mathrm{CdS}-\mathrm{GeS}_{2}$ and the crystal structure of $\mathrm{Ag}_{2} \mathrm{CdGeS}_{4}$. J. Alloys Compd. 2005, 397, 95-98.

(49) Huang, F. Q.; Ibers, J. A. Synthesis, structure, band gap, and electronic structure of $\mathrm{CsAgSb}_{4} \mathrm{~S}_{7}$. J. Solid State Chem. 2005, 178, 212-217.

(50) Krautscheid, H.; Gerber, S. Potassium thiocyanate argentates: $\mathrm{K}_{3}\left[\mathrm{Ag}(\mathrm{SCN})_{4}\right]$, $\mathrm{K}_{4}\left[\mathrm{Ag}_{2}(\mathrm{SCN})_{6}\right]$ and $\mathrm{K}\left[\mathrm{Ag}(\mathrm{SCN})_{2}\right]$. Acta Crystallogr. Sect. C: Cryst. Struct. Commun. 2001, C57, 781-783. 
(51) Gulay, L. D.; Daszkiewicz, M.; Huch, M. R. Crystal Structures of the $\operatorname{Ln}_{4-x} \operatorname{In}_{5-y} S_{13}(\operatorname{Ln}=$ $\mathrm{La}, \mathrm{Ce}, \operatorname{Pr}$ and $\mathrm{Nd} ; \mathrm{x}=0.08-0.12, \mathrm{y}=0.21-0.24), \mathrm{La}_{3} \operatorname{In}_{1.67} \mathrm{~S}_{7}, \mathrm{Gd}_{3} \mathrm{InS}_{6}$, and $\mathrm{La}_{4} \mathrm{Ag}_{2} \mathrm{In}_{4} \mathrm{~S}_{13}$ compounds. J. Solid State Chem. 2008, 181, 2626-2632.

(52) Zhang, J.-P.; Lin, Y.-Y.; Huang, X.-C.; Chen, X.-M. Well-Resolved, New Water Morphologies Obtained by Modification of the Hydrophilic/Hydrophobic Character and Shapes of the Supporting Layers. Inorg. Chem. 2005, 44, 3146-3150.

(53) Hu, T.; Mak, T. C. W. Silver(I) Multiple Salts Assembled with Phosphonate, Perfluorocarboxylate, and the Multinuclear Silver-Ethynediide Supramolecular Synthon. Inorg. Chem. 2013, 52, 9066-9076. 
Table 1. Crystallographic Data and Structure Refinement Details for $\mathrm{Ag}_{5} \mathrm{U}\left(\mathrm{PS}_{4}\right)_{3}$.

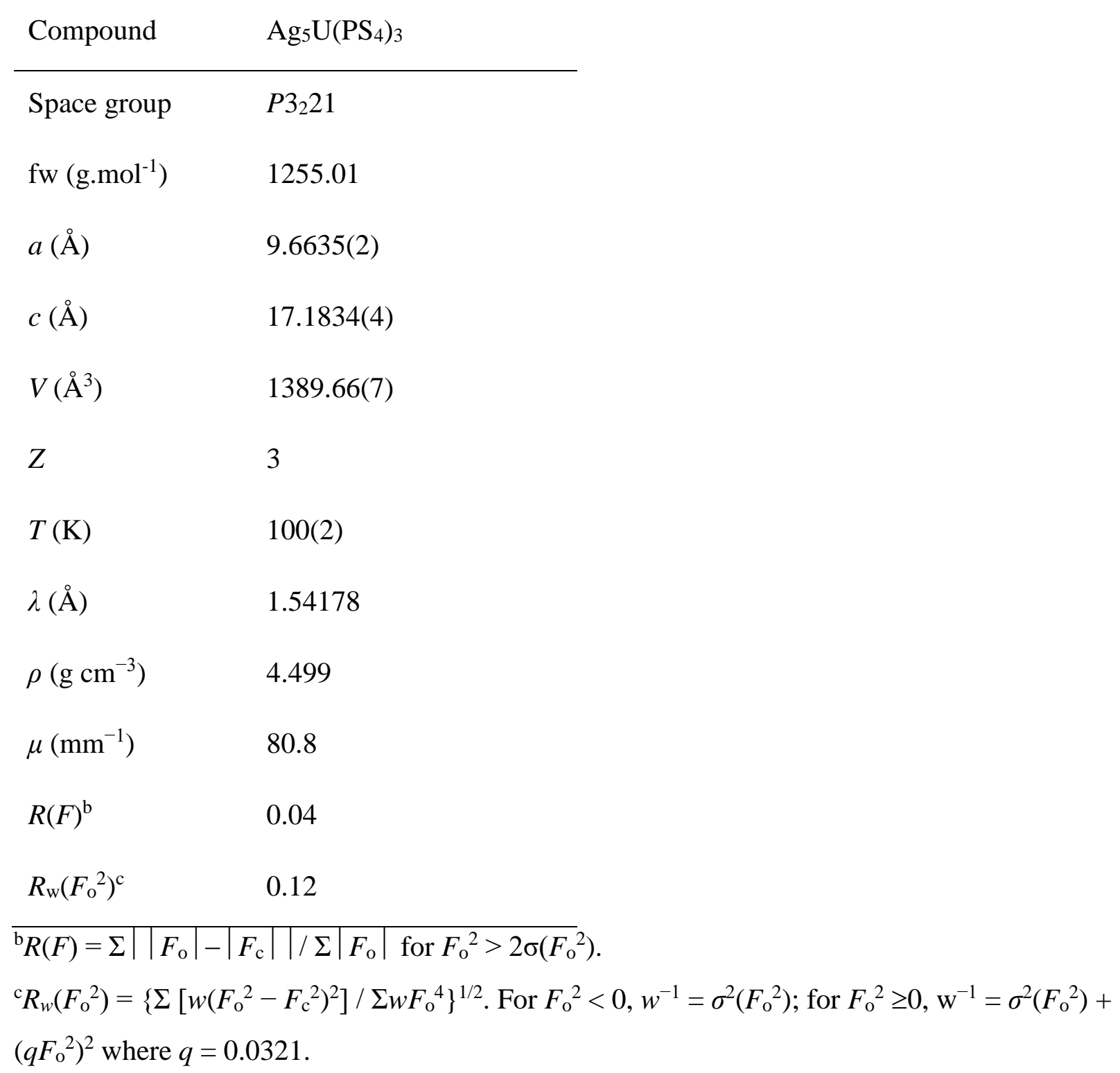


Table 2. Interatomic Lengths $(\AA)$ in $\operatorname{Ag}_{5} \mathbf{U}\left(\mathbf{P S}_{4}\right)_{3}$.

\begin{tabular}{llll}
\hline Atom-Atom & Distance $(\AA)$ & Atom-Atom & Distance $(\AA)$ \\
\hline U1-S4 & $2 \times 2.784(5)$ & Ag3-S6 & $2.510(6)$ \\
U1-S3 & $2 \times 2.786(5)$ & Ag3-S5 & $2.595(5)$ \\
U1-S2 & $2 \times 2.830(5)$ & Ag3-S4 & $2.602(7)$ \\
U1-S5 & $2 \times 2.851(5)$ & Ag3-S1 & $2.917(6)$ \\
& & Ag3-Ag3 & $3.341(6)$ \\
Ag1-S6 & $2.429(6)$ & & \\
Ag1-S4 & $2.430(6)$ & P1-S1 & $2.008(7)$ \\
Ag1-S3 & $2.540(5)$ & P1-S3 & $2.037(7)$ \\
Ag1-S2 & $2.562(6)$ & P1-S6 & $2.062(7)$ \\
Ag1-Ag2 & $3.017(4)$ & P1-S4 & $2.064(7)$ \\
& & & $2 \times 2.032(6)$ \\
Ag2-S6 & $2.590(6)$ & P2-S5 & $2 \times 2.056(6)$ \\
Ag2-S2 & $2.597(6)$ & P2-S2 & \\
Ag2-S1 & $2.681(6)$ & & \\
Ag2-S1 & $2.799(7)$ & & \\
Ag2-Ag2 & $2.774(5)$ & & \\
\hline
\end{tabular}




\section{Figure Legends}

Figure 1. A projection down the [110] direction of the $\mathrm{Ag}_{5} \mathrm{U}\left(\mathrm{PS}_{4}\right)_{3}$ crystal structure.

Figure 2. The $\mathrm{Ag}-\mathrm{S}$ network of the $\mathrm{Ag}_{5} \mathrm{U}\left(\mathrm{PS}_{4}\right)_{3}$ crystal structure.

Figure 3. Total (upper plot) and partial density of states (lower plots) of $\mathrm{Ag}_{5} \mathrm{U}\left(\mathrm{PS}_{4}\right)_{3}$. 


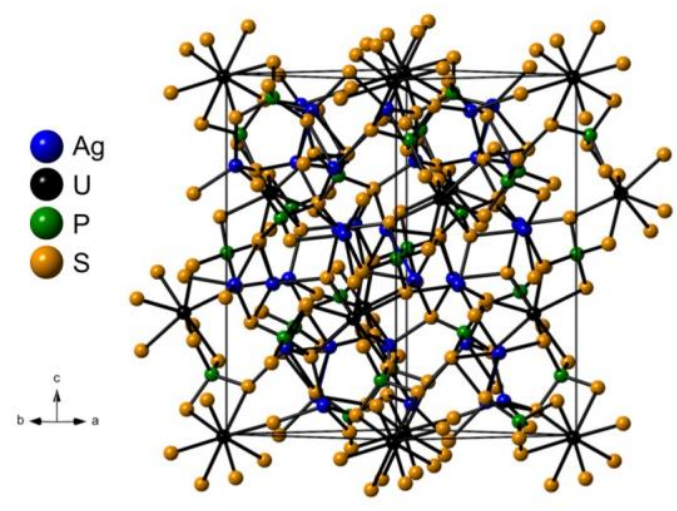

TOCLegend. A projection down the [110] direction of the $\mathrm{Ag}_{5} \mathrm{U}\left(\mathrm{PS}_{4}\right)_{3}$ cryst 